Ann. Biol. anim. Bioch. Biophys., I975, 15 (2), 353-363.

\title{
THE USE OF PROGESTAGENS TO CONTROL THE OESTROUS CYCLE OF THE DAIRY GOAT
}

\author{
J. M. CORTEEL \\ with the technical assistance of G. BARIL, F. BARITEAU, \\ J. Bussière, B. Lebceuf and G. de Montigny \\ Station de Physiologie de la Reproduction, \\ Centre de Recherches de Tours, I. N. R. A., \\ B. P. 1, Nouzilly, 37380 Monnaie (France)
}

\section{SUMMARY}

Seasonal reproduction in the European dairy goat is very marked.

During the breeding season, satisfattory synchronization of oestrus may be obtained with $45 \mathrm{mg}$ FGA vaginal sponges when PMSG is injected at the end of an $18-21$ day treatment. The treated females are systematically inseminated without oestrus detection, using liquid or frozen semen and provided adequate numbers of motile sperm are used, fertility is also satisfactory.

During the non-breeding season, PMSG is injected $4^{8} \pm 2$ hours before the vaginal sponge is removed. Synchronization of oestrus is satisfactory but post-treatment fertility is severely reduced by seasonal and milking anoestrus. However, the effects of both types of anoestrus may be overcome by using relatively large numbers of motile sperm. This is possible when liquid semen is used.

Since it is impossible to deep freeze highly concentrated buck semen owing to the adverse effect of seminal plasma on post-thawing survival of spermatozoa, semen has been preserved, devoid of seminal plasma. Preliminary results indicate that washing, under proper conditions, does not alter the fertilizing capacity of spermatozoa and does improve post-thawing survival of sperm in highly concentrated semen.

Fertilizing capacity of such deep frozen semen is at present being tested in synchronized animals.

Preliminary fertility results are also given in a comparison between a long and a short lasting progesterone treatment.

\section{INTRODUCTION}

An important factor in discussing the use of progestagens for the control of the oestrous cycle in the dairy goat is the marked seasonal reproduction, characteristic of the French breeds. For progestagen treatments to be effective, the 
different problems which arise during the breeding season and in seasonal anoestrus, must be taken into account. This paper discusses these problems and the solutions proposed to overcome them, in terms of artificial insemination and oestrus control.

\section{I. - THE BREEDING SEASON OF THE FRENCH DAIRY GOAT}

In a single flock, ovarian activity and behavioural oestrus are observed only in late summer and throughout the autumn, after several months of complete sexual rest. This is indicated by the percentage of females having ovulations and/or showing behavioural oestrus in each month over a one year period (fig. I). At the onset of

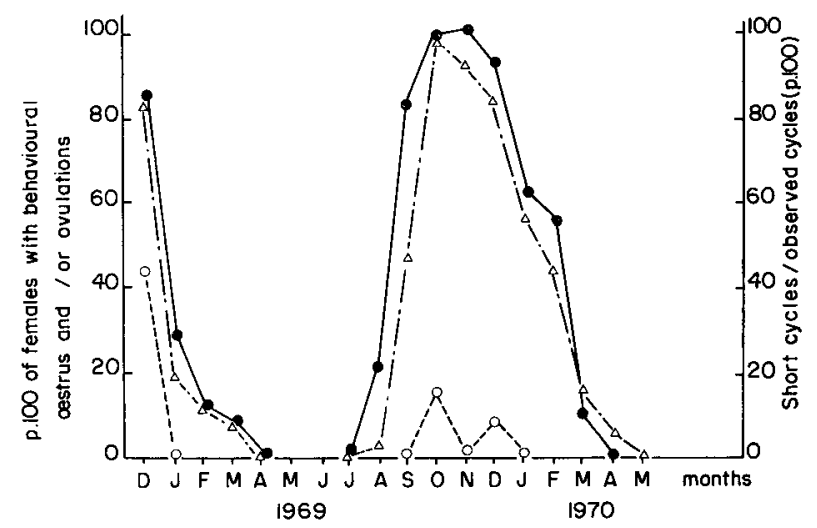

FIG. I, - Seasonal variations in the frequencies of behavioural oestrus $(\Delta-\cdots-\Delta$ : normal cycles; $0-\ldots .0$ : short cycles) and ovulation (- $-\bullet)$ in the french Alpine Goat (CoGNIE, I97O)

the breeding season, ovarian cycles resume in 90 p. Ioo of the females, while oestrous behaviour re-appears in all females in no longer than six weeks (CoGNIE, I970). However, there are highly significant differences among flocks in the average date of onset of the breeding season (CORTEEL, I969; LAHIRIGOYEN, I973).

In a large population, it is three months before $95 \mathrm{p}$. Ioo of females have shown behavioural oestrus for the first time. This is shown indirectly by the monthly frequency of first inseminations in the breeding season, since the large majority of goats are inseminated during the first oestrous cycle of the season (fig. 2; CORTEEL, I97I).

In spite of the flock effect which disperses the resumption of sexual activity, French dairy goats are highly seasonal breeders.

\section{II. - OESTRUS CONTROL BY MEANS OF PROGESTAGENS AND PMSG}

\section{A. - During the breeding season}

Only two progestagens have been widely used to control the oestrous cycle of the goat during the breeding season : MAP and FGA. 
MAP has been given orally (LYNGSET, AAMDAI, and WELLE, I965) or administered by the vaginal route (CoGNIE and CoRTEEL, I970; MrNotakis et al., r972). FGA has been administered exclusively by the vaginal route (BARKER, Ig66; Vlachos, Tsakalof and Vlachos, I966; CoRTeEl et al., I967, I968, I972, 1974).

Both progestagens appear to be effective inhibitors of the oestrous cycle. The subsequent synchronization of oestrus and post-treatment fertility are satisfactory provided adequate doses of gonadotrophic hormones (PMSG and/or HCG) are administered when the treatment ceases (CORTEEL et al., I967; Dhinsda, Hovershand and METCALFE, I969, I97I ; MiNotakis et al., I972).

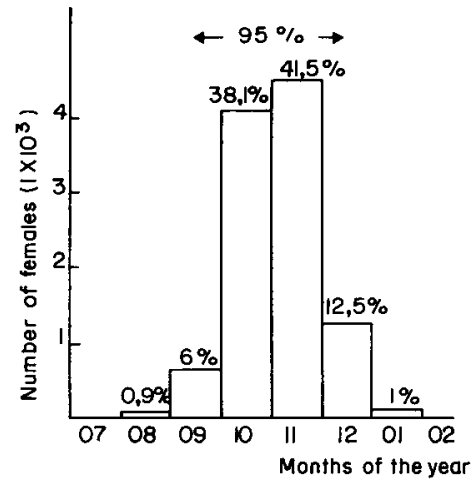

FIG. 2. - Numbers of females inseminated for the first time in the year over a ten year period (CORTEEL, I97T).

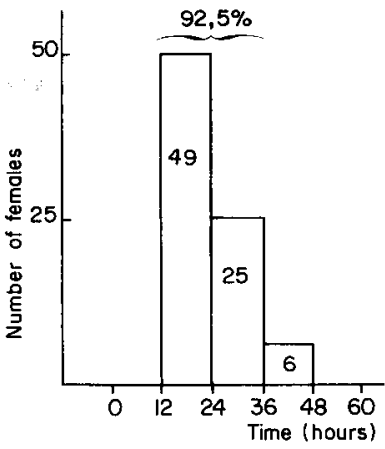

FIG. 3. - Oestrus synchronisation during the breeding season: time between sponge removal and onset of oestrus.

We will summarize here, results obtained with vaginal sponges impregnated with $45 \mathrm{mg}$ FGA, left in place for I8 to $2 \mathrm{I}$ days, 400 IU PMSG being injected at sponge removal. Synchronized oestrus is shown by 95 p. Ioo of treated females, $92.5 \mathrm{p}$. Ioo of these coming into oestrus within a 24 -hour period beginning $\mathrm{r} 2$ hours after sponge removal (fig. 3). Post-treatment fertility is expressed as the percentage of treated goats inseminated on a fixed time basis actually kidding (table $\mathrm{I}$ ).

\section{TABLE I}

Post treatment fertility during the breeding season.

Liquid vs. deep frozen semen

\begin{tabular}{|c|c|c|c|c|c|c|}
\hline $\begin{array}{l}\text { Sponges } \\
\text { removed at }\end{array}$ & $\begin{array}{r}\text { Time } f \\
\text { ren } \\
1 \text { rst a }\end{array}$ & $\begin{array}{l}\text { sponge } \\
\text { to } \\
\text { nd } A I \\
\text { s) }\end{array}$ & $\begin{array}{l}\text { Sperm } \\
\text { stored as }\end{array}$ & $\begin{array}{l}\text { Numbers of motile } \\
\text { sperm per ostrus }\end{array}$ & \multicolumn{2}{|c|}{$\begin{array}{l}\text { Kidding p. } 100 \\
() \text { : number } \\
\text { of females }\end{array}$} \\
\hline 09.00 A.M. & 31 & 55 & liquid semen & 100 to $200\left(10^{6}\right)$ & \multicolumn{2}{|c|}{$55.8(640)$} \\
\hline 09.00 A.M. & 31 & 55 & deep frozen & 40 to $120\left(10^{6}\right)$ & $55.8(448)$ & \multirow{2}{*}{$56.8(769)$} \\
\hline 06.00 P.M. & 36 & 60 & deep frozen & 40 to $120\left(10^{6}\right)$ & $58.3(321)$ & \\
\hline
\end{tabular}


A single AI timing has been used for liquid semen : the sponge is removed in the morning, the first insemination is performed in the afternoon of the following day, and the second insemination 24 hours later. The same timing has been used for deep-frozen semen, and compared with another procedure in which the sponge is removed in the afternoon, the first insemination is done two days later in the morning and the second insemination 24 hours after the first.

Post-treatment fertility is the same whether liquid or deepfrozen semen is used. In the latter case, both AI timings are followed by equivalent fertility rates, but post-treatment fertility decreases with decreasing numbers of inseminated motile sperm (table 2).

TAELE 2

Post treatment fertility during the breeding season. Deep frozen semen. Effect of motile sperm numbers per induced oestrus

( ) : Numbers of females

\begin{tabular}{|c|c|c|c|}
\hline $\begin{array}{c}\text { Mean numbers } \\
\text { of motile sperm }\left(10^{6}\right)\end{array}$ & 120 & 80 & 10 \\
\hline Inseminate volume $(\mathrm{ml})$ & $0 . \overline{5}$ & 0.2 & 0.2 \\
\hline Kidding percentages & $65.2(322)$ & $5^{\prime}+.0(517)$ & $42.5(80)$ \\
\hline
\end{tabular}

B. - Before the breeding season

Experimental data (CoRTEEL et al., I968) have led us to modify the time of PMSG injection before the breeding season. Then, PMSG is injected 48 hours before the sponge is removed. Oestrus is induced in nearly Ioo p. Ioo of treated females, and in $84 \mathrm{p}$. Ioo of these, oestrus occurs in a 24 -hour period beginning I2 hours after sponge removal (fig. 4).

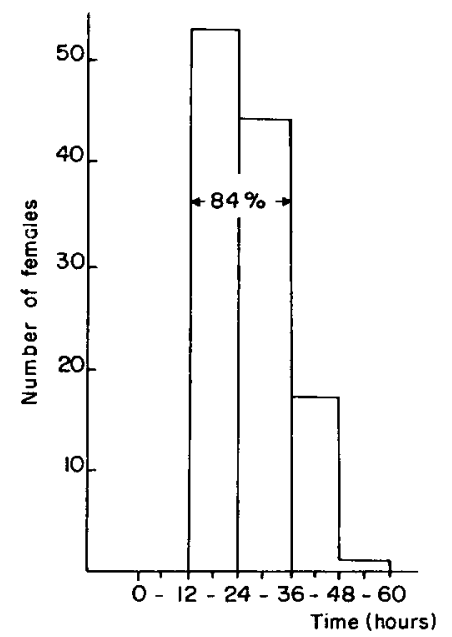

FIG. 4. - Oestrus induction before the breeding season : time between sponge removal and onset of oestrus 
Post-treatment fertility has been measured under standard and varying AI conditions.

I. Under standard AI conditions.

A11 females are inseminated according to the AI timming indicated for liquid semen during the breeding season, and liquid semen is also used (around 200 million motile sperm per female).

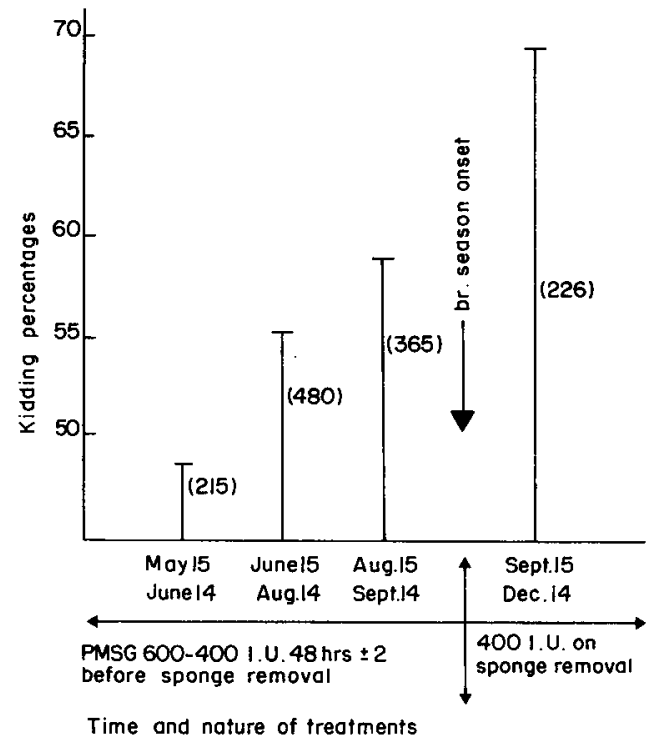

FIG. 5. - Fertility (kidding p. Ioo) of synchronized goats before and after the onset of the breeding season (liquid semen)

( ) : Number of females

Figure 5 indicates that post-treatment fertility increases as the breeding season approaches. Obviously it may be said that seasonal anoestrus is one of the limiting factors of post-treatment fertility. For a given period of treatment, post-treatment fertility also increases with time from parturition to beginning of treatment (fig. 6). It is clear that milking anoestrus is another limiting factor of post-treatment fertility.

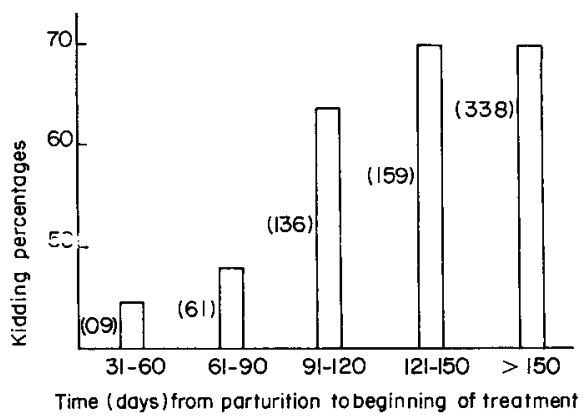

IIG. 6 -. Effect of lactation on post-treatment fertility (liquid semen)

( ) : Number of females 


\section{Under varying $A I$ conditions.}

Females producing significantly different quantities of milk are inseminated with different numbers of motile sperm (table 3 ). When small numbers of motile sperm are used, high milk yields severely depress post-treatment fertility. With increased sperm numbers, the milk effect disappears. When motile sperm numbers are raised again, it seems that the depressive effect of seasonal anoestrus on fertility also disappears.

\section{TABLE 3}

Post-treatment fertility according to milk production and numbers of motile sperm inseminated ( ) : Number of females. Anoestrus period

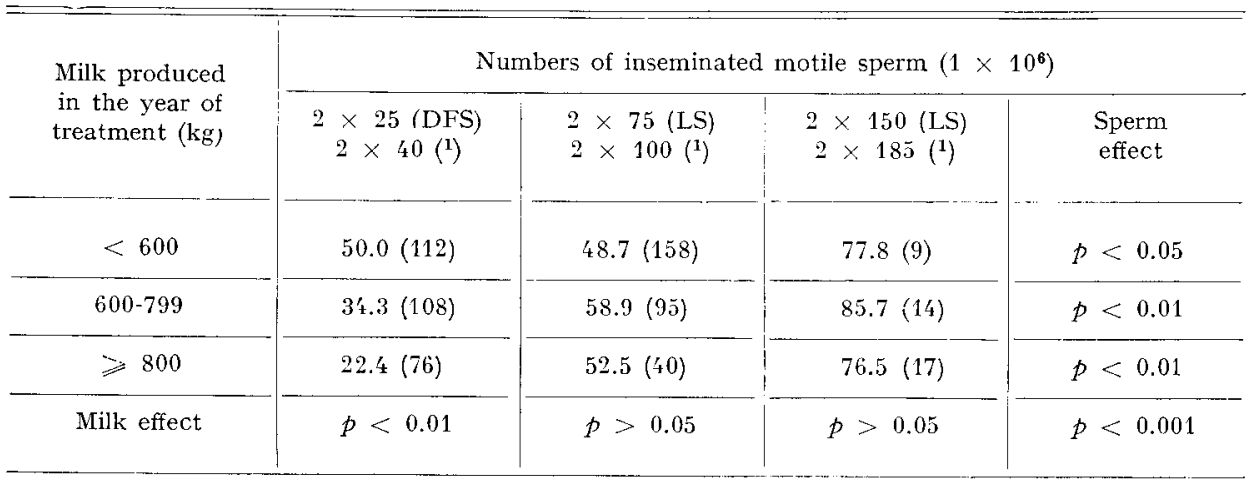

DFS $=$ deep frozen semen, LS = liquid semen.

(1) Kidding percentages.

As previously mentioned for the breeding season, numbers of inseminated motile sperm play a decisive role in post-treatment fertility (table 4).

TABIE 4

Post-treatment fertility before the breeding season : relationship between numbers of motile sperm inseminated and conception rates

\begin{tabular}{c|c|c|c}
\hline $\begin{array}{c}\text { Mean numbers } \\
\text { of motile sperm/oestrus }\end{array}$ & $65\left(10^{6}\right)\left({ }^{1}\right)$ & $175\left({ }^{2}\right)$ & $335\left({ }^{2}\right)$ \\
\hline Conception rates & 40.5 & 52.5 & 80.0 \\
\hline Number of females & $(296)$ & $(293)$ & $(40)$ \\
\hline
\end{tabular}

(1) Kidding percentages (deep frozen semen).

(2) - - (liquid semen). 
III. - EXPERIMENTAL APPROACHES

FOR RAISING FERTILITY BEFORE THE, BREEDING SEASON

\section{A. - Fertility may be raised by increasing the numbers of inseminated motile sperm}

It is possible to do this by using semen at a higher concentration of 500 million sperm per $\mathrm{ml}$ in liquid semen, which cannot be stored for longer than $\mathrm{I} 2$ hours at this concentration. In the past few years, we have never been able to deep-freeze successfully such highly concentrated goat semen. This is probably why we have never succeeded in obtaining a satisfactory post-treatment fertility when deepfrozen semen has been used before the breeding season. An experimental approach is in progress to deep-freeze highly concentrated semen. Experimental data (CoRTEEL, I974) led us to suspect an adverse effect of seminal plasma on post-freezing and -thawing survival of goat sperm, so we have deep-frozen semen devoid of seminal plasma.

By washing the seminal plasma from the semen, in vitro survival of goat spermatazoa is significantly improved before and after deep-freezing. Figure 7 indicates the estimated percentages of motile sperm and motility ratings following glycerol addition (A), upon thawing (B) and two hours later, thawed semen being incubated at $37^{\circ} \mathrm{C}(\mathrm{C})$. The favorable effect of washing is such that it increases by three times, the percentage of deep-frozen-thawed ejaculates suitable for insemination in terms of motile sperm and motility after 2 hours of incubation : 23.2 p. IOO vs 70.0 p. IOO in unwashed and twice-washed semen respectively $(\mathrm{P}<0.0 \mathrm{I})$.

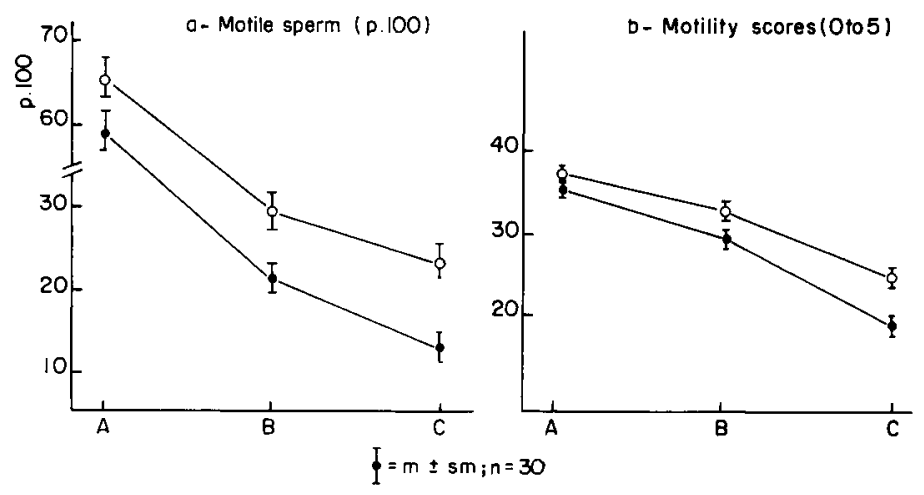

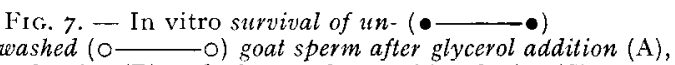
and twice washed $(\mathrm{O}-\mathrm{C}$ goat sperm after glycerol addition
Upon thawing (B) and after two hours of incubation (C). Split ejaculates

Measurement of the fertilizing capacity of twice-washed spermatazoa is in progress. Preliminary results indicate that double washing does not alter the fertilizing capacity of goat spermatazoa in liquid semen : the conception rates 
indicated in table 5 do not differ significantly. The sa meis true for doublewashed semen deep-frozen at a dilution of 300 million sperm per $\mathrm{ml}$ and used in untreated goats. Twice-washed deep-frozen semen containing 500 million sperm per $\mathrm{ml}$ is at present being tested in synchronized animals.

\section{TABLE: 5}

Post-treatment fertility before and during the breeding season : fertilizing capacity of un-and twice-washed he-goat spermatozoa

(Liquid semen. Split ejaculates, $400 \times$ IO $^{6}$ total spz./oestrus)

\begin{tabular}{l|c|c|c}
\hline \hline & Kidding percentages & $\begin{array}{c}\text { Number of } \\
\text { females }\end{array}$ & $\begin{array}{c}\text { Statistical } \\
\text { difference }\end{array}$ \\
\hline $\begin{array}{l}\text { Un-washed spz. } \\
\text { Twice-washed spz. }\end{array}$ & $60.4 \%$ & 48 & $\mathrm{P}>0.05$ \\
\hline
\end{tabular}

Thus, it is reasonable to think that subfertility may be overcome by adapting AI conditions to the synchronizing treatment. The other approach is to modify the synchronizing treatment itself.

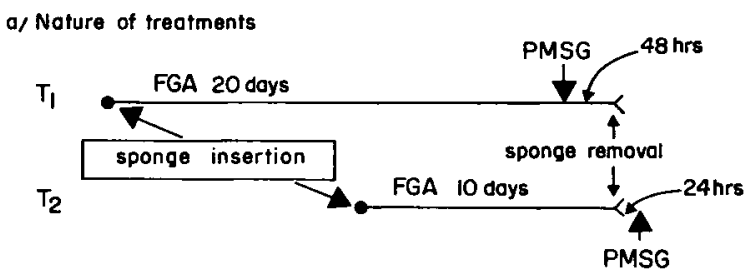

b/ Females in ostrus

$T_{1}:\|/\|$

$T_{2}: 9 / 11$

c/ Time from sponge removal to the onset of oestrus

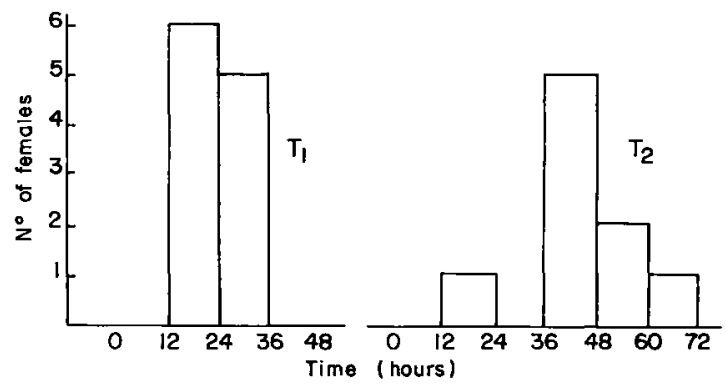

FIG. 8. - Long VS short progestogen treatment before the breeding season 


\section{B. - Comparison between a short and a long progestagen treatment with different times of PMSG injection (fig. 8)}

Shortening the FGA treatment (ro days) and modifying the time of PMSG injection (24 hours after sponge removal) led to a more dispersed synchronization of oestrus, but this has to be confirmed in a larger number of animals. In spite of this apparent dispersion in oestrus synchronization, the same AI timing as that used after a 20 day treatment does not decrease post-treatment fertility when liquid semen is used (table $6 a$ ). A more suitable AI timing might improve post-treatment fertility in the short treatment. The AI timing indicated in table $6 b$ was tested in too small a number of animals to be analyzed satisfactorily in statistical terms, and remains to be improved.

TABLE 6

Long vs. short progestogen treatment for the induction of oestrus before the breeding season : post-treatment fertility (pregnancy rate)

Liquid semed $200 \times$ Io $^{6}$ motile sperm per oestrus

\begin{tabular}{|c|c|c|c|c|c|}
\hline \multicolumn{3}{|c|}{$\begin{array}{l}\text { a) All goats inseminated blindly } \\
31 \text { and } 55 \text { hours after sponge removal }\end{array}$} & \multicolumn{3}{|c|}{$\begin{array}{l}\text { b) Short treatment for all goats inseminated } \\
31-55 \text { or } 55-79 \text { hours after sponge removal }\end{array}$} \\
\hline & $\begin{array}{l}\text { Percentage } \\
\text { pregnant } \\
\text { (progesterone } \\
\text { assay) }\end{array}$ & $\begin{array}{l}\text { Number of } \\
\text { females }\end{array}$ & & $\begin{array}{l}\text { Percentage } \\
\text { pregnant } \\
\text { (progesterone } \\
\text { assay) }\end{array}$ & $\begin{array}{l}\text { Number of } \\
\text { females }\end{array}$ \\
\hline $\begin{array}{l}\mathrm{T}_{1} \\
\mathrm{~T}_{2}\end{array}$ & $\begin{array}{l}55.4 \\
56.8\end{array}$ & $\begin{array}{l}83 \\
81\end{array}$ & $\begin{array}{l}31-55 \\
55-79\end{array}$ & $\begin{array}{l}65.0 \\
72.2\end{array}$ & $\begin{array}{l}20 \\
18\end{array}$ \\
\hline
\end{tabular}

\section{CONCLUSION}

According to the data presented, it may be said that the administration of progestagens and PMSG is a dependable technique for oestrus control and AI during the breeding season of the dairy goat.

Before the breeding season, the depressive effects of seasonal and milking anoestrus may be corrected by increasing the numbers of motile sperm, but this remains to be proven when using deep-frozen semen. However, this method of increasing post-treatment fertility is highly sperm-consuming. The other approach, that is, a modification of the synchroizing treatment may be more benefical, provided the new treatments do not alter the mechanisms supporting fertility, especially sperm. transport in the genital tract of the female. 


\section{RÉSUMÉ \\ UTILISATION DES PROGESTAGÈNES POUR LA MAÎTRISI: DES CYCI.ES SEXUELS CHEZ LA CHÈVRE LAITIÈRE}

Les chèvres laitières européennes ne se reproduisent naturellement qu'en fin d'été et tout au long de l'automne. Ceci conduit à considérer le contrôle et l'induction du cycle sexuel en période d'activité et de repos sexuels.

Pendant la période d'activité sexuelle, une synchronisation satisfaisante des œstrus peut être obtenue à l'aide d'éponges vaginales (FGA $45 \mathrm{mg}$ ) maintenues en place I8-2I jours et une injection de 400 UI de PMSG effectuée au moment du retrait de l'éponge. Lorsque les femelles traitées sont inséminées sans clétection d'œestrus, à des moments précis après la fin du traitement, la fertilité à l'ostrus induit est satisfaisante, que l'on utilise du sperme conservé quelques heures à l'état liquide ou du sperme congelé : 55,8 contre 56,8 p. Ioo de mise-bas pour 640 et 769 chèvres respectivement. Ave le sperme congelé, la fertilité augmente très significativement avec le nombre de spermatozoïdes mobiles inséminés : 42,5; 54,0 et $65,2 \mathrm{p}$. Ioo de chèvres mettant bas pour 40, 80 et I 20 millions de spermatozoïdes fléchants.

Pendant la période d'inactivité sexuelle, l'injection de PMSG est effectuée $48 \pm 2$ heures avant le retrait de l'éponge vaginale pour une durée de traitement et une dose de FGA identiques à celles utilisées en période d'activité sexuelle. Lá synchronisation des oestrus induits est satisfaisante. La fertilité à l'œstrus induit varie en fonction de la saison (subfertilité liée à l'anoestrus saisonnier) et en fonction de l'intervalle parturition - début de traitement (subfertilité liée à l'anœstrus de lactation). En augmentant le nombre de spermatozoïdes mobiles inséminés, il est possible de corriger l'effet dépressif de ces deux types d'anœstrus, mais ceci n'a jusqu'ici étá possible qu'avec le sperme conservé à l'état liquide pendant seulement iz heures.

Les difficultés rencontrées pour congeler le sperme de bouc peu dilué ont été surmontées par la mise au point d'une nouvelle technique de congélation dont l'efficacité est démontrée eu égard à la survie in vitro des spermatozoïdes. La mesure de la "fécondance " de ces spermatozoïdes est en cours et les résultats préliminaires indiquent que cette fécondance n'est pas altérée par le nouveau procédé de congélation. Il est donc permis de penser que la subfertilité liée aux ancestrus saisonnier et de lactation pourra également être corrigée avec le sperme congelé.

Si l'adaptation des conditions d'insémination aux états physiologiques de l'animal doit permettre d'obtenir une fertilité élevée tout au long de l'année, cette adaptation entraine néanmoins l'utilisation de nombres de spermatozoïdes importants. Il paraît donc souhaitable d'améliorer aussi le traitement hormonal. Les résultats préliminaires d'essais allant dans ce sens sont indiqués.

\section{REFERENCES}

BARKER C. A. V., r966. Synchronization of oestrus in dairy goats by progestin impregnated vaginal pessaries. Can. Vet. J., $7,215-218$.

Cognie Y., I97o. (Personal communication).

Cognie Y., Cortelel J. M., ig7o. (Unpublished data).

Corteel J. M., Mauleon P., Thimonier J., Ortavant R., r967. Essais d'obtention de gestations synchrones avant le début de la saison sexuelle de la Chèvre à l'aide de I $7 \alpha$-acetoxy, $9 x$-fluoro, I I $\beta$ hydroxy-pregn-4-ène- 3,20 dione administré par la voie vaginale. Ann. Zootech., 4, 343-350.

Corteel J. M., Mauleon P., Thimonier J., Ortavant R., ig68. Recherches expérimentales de gestations synchrones avant le début de la saison sexuelle de la Chèvre après administration vaginale d'acétate de fluorogestone et injection intramusculaire de PMSG. VIth Intern. Cong. anim. Reprod. artif. Insem., 2, I4II-I 4 I2.

CORTEEL J. M., I969. Déplacement synchrone de la saison sexuelle de chèvres multipares à l'aide de traitements hormonaux. Journée d'étude des problèmes de sélection caprine, Rambouillet (France), I I février.

Corteel J. M., ig7r. La maîtrise du cycle sexuel chez la Chevrette et chez la Chèvre. Bull. Tech. Inform. Minist. Agric., 257, I75-I80.

Corteel J. M., Courot M., Ortavant R., I972, Fertility of multiparous goats inseminated with liquid or deep frozen semen after hormonal synchronization of oestrous before the onset and in the course of the breeding season. VIIth Intern. Cong. anim. Reprod. artif. Insem. P., 2, roro-1or3. 
Corteel J. M., Courot M., Ortavant R., I974. Fertility of synchronized multiparous goats inseminated with liquid or deep frozen semen. Intern. Symp. on Physiopathology of Reproduction and Artificial Insemination in small ruminants. Thessaloniki, May i6-19.

Corteel J. M., I974. Viabilité des spermatozoïdes de bouc conservés et congelés avec ou sans leur plasma séminal : effet du glucose. Ann. Biol. anim. Bioch. Biophys., 14, 741-745.

Dhindsa D. S., Hoversland A. S., Metcalfe J., ig69. Oestrus control in goats with cronolone sponges and PMSG. J. Anim. Sci., 29, I87-188.

Dhindsa D. S., Hovfrsland A. S., Metcalfe J., I97I. Reproductive performance in goats treated with progestogen impregnated sponges and gonadotrophins. J. Anim. Sci., 32, 30I-305.

Lahirigoyen M., i973. Contribution à la définition d'un plan de testage des caprins. Mémoire de fin d'études. École Supérieure d'Agriculture de Purpan, Toulouse.

Lyngset O., Aamdal J., Velle W., I965. Artificial insemination in the goat with deep frozen and liquid semen after hormonal synchronization of oestrus. Nord. Vet. Med., 17, I78-18I.

Minotakis C. S., Xenoulis P. C., Kouras A., Samara D., rg72. The use of Map-impregnated pessaries in stall-fed goats and the effect of low PMSG dosage. VII intern. Congr. anim. Reprod. artif. Insem., Munich., 2, 1005-1008. 